\title{
Considerations for the Emergency and Perioperative Management of Patients with COVID-19
}

\author{
Galvan Talamantes Yazmin ${ }^{1}$, Vega Felipe ${ }^{2}$, Mercedes N Lopez-Hernandez ${ }^{3}$, Alvarez Reséndiz G Esteban ${ }^{4}$
}

\begin{abstract}
The COVID-19 pandemic is a threat to global health, which is multiplying rapidly due to its high degree of contagiousness; some of these patients will require surgical services and anesthesia care for endotracheal intubation. Protecting staff members and preventing cross transmission of infection during airway approaches and surgical procedures for patients with known or suspected COVID-19 infection is paramount, preserving the capacity of health systems. Careful planning, consensual clinical decision-making, and rigorous personal protective equipment (PPE) will be required; avoid performing nonessential or urgent surgical procedures that generate greater viral exposure. The medical teams during the perioperative period will face unexpected inconveniences therefore, and due to the continuous management, that is evolving, this article aims to discuss the essential PPE, describe the modifications in the management of the airway, and cite the particular precautions consequent to the surgical act.
\end{abstract}

Keywords: COVID-19, Intubation, Perioperative management, Personal protective equipment, Surgery.

\section{Resumen}

La pandemia por COVID-19 es una amenaza a la salud mundial, que se multiplica velozmente por su alto grado de contagiosidad, algunos de estos pacientes necesitaran servicios quirúrgicos, y cuidados de anestesia para la intubación endotraqueal por su estado crítico. Es primordial proteger al personal y prevenir la transmisión cruzada de la infección durante los abordajes de la vía aérea y procedimientos quirúrgicos para pacientes con infección conocida o sospechosa de COVID-19, preservando la capacidad de los sistemas de salud. Se requerirá de una planificación cuidadosa, toma de decisiones clínicas consensuadas y de un riguroso equipo de protección personal (EPP), evitando realizar procedimientos quirúrgicos no esenciales o urgentes que generen mayor exposición viral y desabasto de material. Los equipos médicos durante el perioperatorio se enfrentarán a inconvenientes inesperados por lo tanto y debido al manejo continuo que esta evolucionando, el presente articulo tiene por objetivo discutir el EPP indispensable, describir las modificaciones en el manejo de la vía aérea y citar las precauciones particulares consecuentes al acto quirúrgico.

Palabras clave: COVID-19, Intubación, Manejo perioperatorio, Cirugía, EPP.

Panamerican Journal of Trauma, Critical Care \& Emergency Surgery (2020): 10.5005/jp-journals-10030-1280

\section{INTRODUCTION}

In December 2019, a new pneumonic syndrome was reported in the Chinese City of Wuhan, an infection caused by a novel coronavirus (SARS-CoV-2) that leads to the coronavirus disease 2019 (COVID-19) ${ }^{1}$ syndrome. The imminent international spread of this potentially lethal virus has caused concern worldwide with 3,534,544 cases and 248,169 deaths reported so far. $^{2}$

The problem extent has been catastrophic, and, while it was at a certain point minimized before it came out of the Asian continent, it is a problem that may well be considered to be an emergency crisis of the highest nature ${ }^{3}$ for the health systems. Thus, it can be equaled to a disaster because it exceeds hospital capacities in terms of assistance and resources; nor is it an easy situation where we can hope for international help, since their health systems are in an unmanageable situation. Besides assisting patients presenting with this new pathology, hospital services must continue to respond to common, expected emergencies. Different recommendations from medical associations and international agencies have stated the need to defer elective surgical and endoscopic procedures. Healthcare services must have quality and safety strategies/permanent guidelines that must also cover natural disasters, war, and pandemics, which are crucial in the current situation. ${ }^{4}$ The goal of deferring elective procedures in this time of pandemic originates in a number of situations. One of them is the need to have access to more rooms in hospital facilities
1,3,4 Department of Anesthesiology, Hospital Ángeles Lomas, Mexico City, Mexico

${ }^{2}$ Department of Surgery, Hospital Ángeles Lomas, Mexico City, Mexico Corresponding Author: Mercedes N Lopez-Hernandez, Department of Anesthesiology, Hospital Ángeles Lomas, Mexico City, Mexico, Phone: +52 5535674471, e-mail:wniclop.09@gmail.com

How to cite this article: Yazmin GT, Felipe V, Lopez-Hernandez MN, et al. Considerations for the Emergency and Perioperative Management of Patients with COVID-19. Panam J Trauma Crit Care Emerg Surg 2020;9(2):133-141.

Source of support: Nil

Conflict of interest: None

with available spaces to accommodate more patients. Also, to have more mechanical ventilators available in case of an increase in demand, and to prevent adverse events for patients undergoing low-morbimortality procedures, which are expected, but which can become lethal due to COVID-19 infection of asymptomatic individuals. ${ }^{5}$ The efforts must be focused on ensuring planning and care strategies directed to health staff to perform emergency surgeries during the pandemic. This includes: (1) to ensure proper treatment for patients with trauma, digestive bleeding, or a severe infection, for example, who require an immediate surgery; (2) to prepare and guide all the health professionals on how to act, 
protecting themselves with personal protective equipment (PPE), and (3) to allow only a minimum number of people required in the surgical room, thus avoiding the risk of contaminating other people. To this effect, this is a mandatory perception of quality and safety initiatives for disasters and pandemics. ${ }^{6}$

\section{On the Enemy and Its Transmission}

Patients infected with COVID-19 may develop a severe acute respiratory infection followed by pneumonia, quickly evolving into acute respiratory distress (ARDS) and systemic multiple organ failure. ${ }^{7}$ COVID-19 can be transmitted through aerosols, aerated solids, fluid from secretions, human discharges, as well as droplets from breathing, coughing, sneezing, and contact with surfaces. ${ }^{8}$ The surgical staff members must protect themselves in advance as per the protocols and guidance established by each health institution. The transmission mechanism of viral pathogen agents takes place through contact paths; contamination of PPE, clothing, skin, and face mucous membranes accounts for the main infection vehicles for health workers (HWs), which results in vulnerability thereof with a high risk of spreading the pathogen through the healthcare setting, or, unfortunately enough, in severe illness or death. ${ }^{9}$ A report published by Linh, where the extent of virus contamination in PPE, skin, and clothing of HWs) was assessed in patients with acute viral infections documented a high rate of spread, evidencing habitual contamination upon PPE removal after taking care of the patient. ${ }^{10}$ In relation to the recommendations published on the surgical act to cancel elective surgeries, there exists controversy and opposition; however, mathematical models have been documented, which predict preventable infections of at least 75.9 patients and $75.9 \mathrm{HWs}$ within 30 days if the elective procedures continued within a conventional routine. ${ }^{11}$ Following the statement made by the World Health Organization (WHO), which classified it as an international emergency and gave it the status of a pandemic, the Surgeon General of the United States proclaimed a formal notice to cancel elective surgeries due to the increase in the coronavirus spread within hospital facilities and possible depletion of the medical resources necessary to manage a potential increase in the cases of coronavirus. ${ }^{12}$ It is worth mentioning the recommendations made by the American College of Surgeons (ACS) calling to prioritize the proper allocation of resources during the pandemic, and the decision to intervene elective procedures must be taken in context based upon numerous considerations, both medical and logistic. ${ }^{13}$

Likewise, the Committee on Trauma (COT) of the ACS sets up recommendations for the directors of trauma and the trauma response teams in emergency rooms and trauma centers, applying the following care strategies. Assessment of the trauma patients must not be delayed so as to determine their COVID-19 status, but proper precaution measures must be taken. That is, assuming that any patient being admitted in the hospital for this condition is positive. To ensure the strict use of PPE to prevent contact with droplets for all the patients and to intensify the protection recommendations starting from preparation for the arrival of injured and hurt patients. If a patient has upper respiratory tract symptoms, immediately put a mask on the patient's mouth. Ask a series of questions about presence of fever and upper respiratory tract symptoms associated to COVID-19, establish an exposure history and a trip history, and implement proper isolation measures. Another recommendation is to minimize the number of regular staff members who will assist these patients, allow only those required for the direct care of the patient, and, last, develop policies and procedures for managing the airway for the patients potentially having COVID-19 who require emergency intubation. ${ }^{14}$

So, this article intends to cover all the aspects of managing the airway in emergency and the perioperative period during this pandemic in order to provide the healthcare personnel, predominantly the anesthesiology team and the surgical personnel, with safety.

\section{Personnel Protection Measures}

\section{Hand Hygiene}

Frequent handwashing is the most important hygiene measure when protecting against crossed infection, and it must be taken on an ongoing basis. ${ }^{15}$ Handwashing 2-3\% hydrogen peroxide gels or sinks with water and soap must be placed near every anesthesia station. Hand hygiene must be thoroughly performed as per standardized guidelines particularly after removing gloves, after having contact with dirty or contaminated areas, before touching the anesthesia machine, after every contact with the patient, and before and after putting on or removing PPE.

\section{Personal Protective Equipment}

Departments and hospitals must make PPE available to every HW who is in direct contact with the patient. Algorithms must be in place to put on and remove PPE as per standardized protocols. An external observer is recommended to oversight thoroughly the performance based on a checklist. ${ }^{16}$ Ongoing training is required for all the personnel. Consideration should be given to conducting mock intubation and extubation drills in critical and noncritical environments with PPE on. ${ }^{17}$ PPE includes a mask, safety glasses, a face shield, several pairs of gloves, gowns, a cap, and boots. Whenever possible, the maximum protection level available should be used, particularly for aerosol-generating procedures. Experiences in other countries and continents have shown that PPE supplies have been insufficient to meet the demand, so a centralized storage site with controlled distribution is recommended, as well as to consider preparing specific PPE kits as per the WHO recommendations. ${ }^{18}$

The PPE may be a limited resource in some parts around the world, and assisting measures are often required for the personnel to be protected against aerosols and droplets, like the acrylic box. Since this is a barrier that may be easily built at a low cost, it may be used not only during the intubation process but also during the extubation one. ${ }^{19}$

The PPE scarcity is currently a big challenge for the health system in many countries, so reusing the piece of equipment has become an option in order to maintain availability of supplies. Table 1 summarizes the measures that can be implemented to optimize resources. ${ }^{20-23}$

\section{Masks}

This coronavirus, SARS-CoV-2, has a size of $0.06-0.14 \mu \mathrm{m}$. It is transported by droplets of over $0.3 \mu \mathrm{m}$ and, therefore, the respirator facepieces with a filter for particles $>0.3 \mu \mathrm{m}$ are appropriate. N95 masks comply with the efficacy criteria established by the National Institute for Occupational Safety and Health (NIOSH) and are approved for protection against transmission through airborne droplets and $95 \%$ of particles over $0.3 \mu \mathrm{m}$ in size. In Europe, P1 or FFP1 means that $80 \%$ of airborne particles will be filtered; P2 or FFP2, 94\%; and P3 or FFP3, 99.95\%. As a minimum, N95 masks must be worn for all suspected or confirmed cases of COVID-19 infection. ${ }^{24}$ 
Table 1: Measures that can be implemented to optimize resources

\begin{tabular}{|c|c|c|}
\hline$P P E$ & Method & Special considerations \\
\hline \multirow[t]{3}{*}{ N95 mask } & Ultraviolet germicidal irradiation & $\begin{array}{l}\text { Verify the N95 physical integrity (verify straps, the nose } \\
\text { clip, and proper sealing). }\end{array}$ \\
\hline & Vaporous hydrogen peroxide & - Consider the manufacturer's recommendations. \\
\hline & Moist heat & \\
\hline Gown & $\begin{array}{l}\text { Wearing a cloth gown instead of a disposable one } \\
\text { Extending the use of the gown with more than one patient } \\
\text { who is located in the same isolation room }\end{array}$ & $\begin{array}{l}\text { In case the gown has a hole, it can be repaired; verify the tying } \\
\text { straps are in good shape. If the gown is visibly dirty, it must be } \\
\text { removed and discarded. }\end{array}$ \\
\hline Goggles & $\begin{array}{l}\text { While wearing gloves, clean the external and internal } \\
\text { surface of the goggles with a sanitizing solution and } \\
\text { thoroughly dry in the air or with drying wipes }\end{array}$ & Verify proper sealing and visibility of the goggles. \\
\hline \multirow[t]{2}{*}{ Gloves } & $\begin{array}{l}\text { Wear the same gloves when the patients are in the same } \\
\text { isolation room, but make sure to disinfect them between } \\
\text { patients to avoid crosstransmission of pathogens. }\end{array}$ & $\begin{array}{l}\text { They must always be discarded when they have evident } \\
\text { contamination from blood, respiratory secretion, or other } \\
\text { body fluids, or when they are damaged. }\end{array}$ \\
\hline & & - Maximum time use: 4 continued hours. \\
\hline
\end{tabular}

\section{Technique}

Before putting the mask on, the individuals must wash their hands with soap and water or hand sanitizer. The mask must cover their mouth and nose perfectly, making sure there is no space between their face and the mask. This can be checked after fitting the mask and the metallic zone many of them have to the nose, and performing a breathing test, verifying there is a proper sealing and there is not a possibility for air to come in or out between the mask and the eyes.

\section{An Alternative to Masks? Powered Air-purifying Respirator}

There is a debate in regards of using powered air-purifying respirators (PAPR) vs $\mathrm{N} 95$ masks in aerosol-generating procedures. ${ }^{25}$ While PAPRs have a higher protection factor than N95 respirators, there is no concluding evidence that PAPRs will reduce the probability of viral transmission in the context of possible aerial spread. However, PAPRs may be more comfortable to wear for prolonged resuscitation events; unexpected adjustments are avoided, and they fully cover head and neck, thus providing additional protection. ${ }^{26}$ According to reports published on patients with SARS, HWs were infected during resuscitation in spite of wearing $\mathrm{N} 95$ masks. ${ }^{27}$ Wax recommends PAPRs for high-risk resuscitation scenarios in patients with confirmed or suspected infection with COVID-19, mentioning as some disadvantages of introducing PAPR as PPE, challenges in training doctors in the safe removal of the equipment without contaminating it, cleaning it for the next use, availability, and access. ${ }^{28}$

There are some devices similar to diving suits (Fig. 1) with an AAMI 4 protection level as per the Association for the Advancement of Medical Instrumentation (AAMI), meaning the highest protection level, which offer additional protection without being powered air purifiers, but which have shown lower viral concentrations within the diving suit, but their use is recommended with the proper protection equipment (N95) and eye protection ${ }^{29}$ (Fig. 2).

\section{Gloves}

There are different types of material, the most common ones being latex, vinyl, and nitrile, from which the last one offers the highest protection; however, disposable gloves without a lining are recommended. ${ }^{30}$ Everyone participating in perioperative care must wear them. It is recommended to wear double gloves when

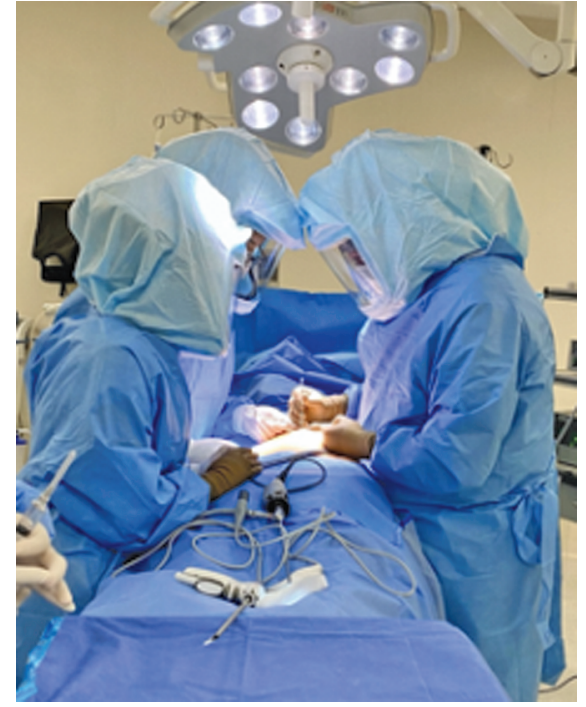

Fig. 1: Personal protective equipment similar to a diving suit with AAMI 4 protection

manipulating the respiratory tract, blood, urine, and other patient's body fluids. Special care must be applied to wearing the first pair of gloves under the surgical gown or protecting suit, and then put on the regular pair of gloves. The gown sleeve must reach up to the first glove palm so that there are not uncovered zones that may allow for filtration, and the second pair must cover several centimeters above the surgical gown or the protective equipment. There are some lowquality short gloves, which do not properly fit, and which fail to cover the forearm's distal third, and they may easily tear and slip. In view of this, it is preferable to have the proper material as far as possible to avoid contagion as a result of improper low-quality equipment.

\section{Gowns}

It is recommended to wear fluid-resistant disposable longsleeve surgical gowns, specifically for aerosol-generating procedures (tracheal intubation, noninvasive ventilation, tracheostomy, cardiopulmonary resuscitation, manual ventilation before intubation, bronchoscopy); however, there are some reviews approving airborne pathogen-resistant gowns made of polyethylene, with a full-length zipper, or nuclear protection equipment. ${ }^{31}$ 


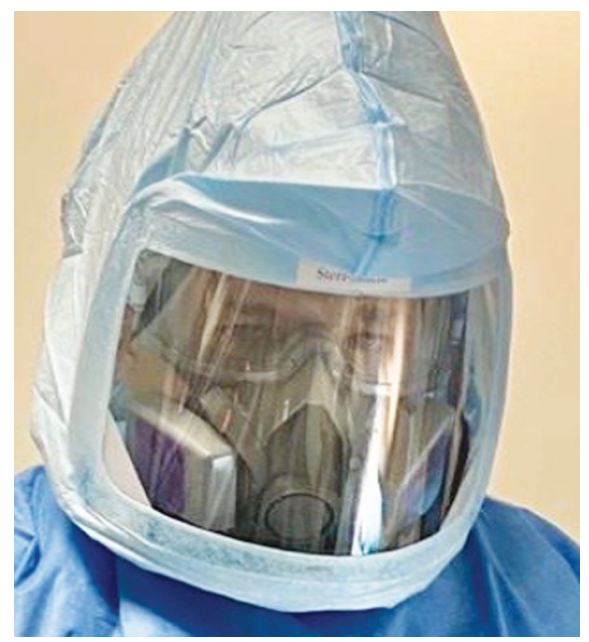

Fig. 2: Personal protection equipment with double protection during an aerosol generating procedure. Mask with N95 filters and goggles

\section{Face Shields and Eye Protection}

Face shields have protective features against airborne transmission, mainly through exhaled droplets. Their use is recommended when N95 masks are scarce. ${ }^{32}$ Goggles and face shields must be available to prevent the eye mucous membrane from being exposed to the virus. Goggles must fit the user's features.

\section{Approach to the Airway}

According to international protocols cited by the WHO and shared experiences in scientific evidence, management of the airway for this and other highly infectious virus outbreaks will require rigorous preparation. ${ }^{16,28,31,33-35}$ During tracheal intubation, the health professionals face high viral loads, this act accounting for the highest exposure risk. ${ }^{33}$ Before intubation, you must protect yourself with full PPE, which represents a fundamental priority for the anesthetist. The anesthetist can rely on visual cognitive aids, checklists, and airway approach strategies planned in advance. ${ }^{36}$ The procedures must be performed in a negative pressure chamber (where available) or in an isolation area, which is fully equipped with emergency airway equipment, tested resuscitation equipment, loaded quick sequence induction drugs, available suction, ready video laryngoscopy equipment, monitor, and ventilator. A team will be required that includes assistants in the area (ICU personnel, other anesthetists, nurses) defining roles in advance and having a staff member serving as external evaluator who monitors access and exit to and from that area, always restricting the number of people present to avoid unnecessary risks (Fig. 3). The most expert person in intubation must perform the maneuver optimizing it to succeed on the first attempt. Preoxygenation must be performed for a minimum 3 minutes with 100\% oxygen, avoiding bag-mask ventilation. Should mask-positive ventilation be required due to critical arterial oxygen saturation events, some authors recommend to cover the area around the patient's mouth and nose with wet pieces of gauze to help prevent spread of the virus by applying ventilation in low volumes. ${ }^{34,37}$ Rapid sequence intubation is indicated for all cases, minimizing apnea time during which a significant aerosolization can be produced with manual ventilation. A sensible administration of anesthetic agents is recommended to avoid the hemodynamic instability that coincides with a low oxygen saturation and the patient's decreased oxygen reserve, especially for those severely sick. Likewise, it is equally important to provide the optimal dose for a deep neuromuscular blockade with a rocuronium dose of $1.2 \mathrm{mg} / \mathrm{kg}$, preventing coughing and the added aerosolization. Sellick maneuver is not recommended since it can compromise the optimal ventilation; it shall only be used in select cases. ${ }^{38}$ Laryngoscopy must be used, ideally, with a screen separate from the blade to prevent the person performing intubation from placing their face near the patient. If a difficult airway is anticipated, a single-use intubation with flexible bronchoscopy (FB) can be performed. It is recommended to introduce the endotracheal tube with a guide wire to increase the success rate. ${ }^{39}$ In situations where two attempts have failed and we come across an emerging way, consideration must be given to second-generation supraglottic devices of which a notable example is the laryngeal mask (LMA)Protector, which is always used with a premounted FB with a tracheal tube and connected to an oxygen source with the aim to extend safe apnea time and minimize desaturation during execution. ${ }^{40}$ In unfortunate extreme cases, not to delay surgical or percutaneous airway for rescuing the airway in spite of the aerosolization potential. ${ }^{41}$ Collocation of the endotracheal tube must be confirmed through a capnography and by looking at the thoracic wall movements; auscultation is not advisable due to the challenges posed by the PPE and the risk of cross contamination. ${ }^{34}$ If there are no counter-indications due to a full stomach or a risk that food will reflux, the epigastrium can be gently pressed to check for proper lifting of the thorax while performing this maneuver. Once intubated, excessive manipulation of the tracheal tube must be avoided, immediately connecting it to the ventilator, and protective mechanical ventilation strategies must be used, such as: target current volume $6 \mathrm{~mL} / \mathrm{kg}$ of the predicted weight, plateau pressure lower than $30 \mathrm{~cm} \mathrm{H}_{2} \mathrm{O}$, target $\mathrm{SaO}_{2} 88-95 \%$, and $\mathrm{pH}$ higher than 7.25 . $^{42}$ The ventilator must have filters installed at the outlets or use heat and moisture exchangers (HMEs) between the exhalation port and the endotracheal tube. ${ }^{43}$ All the contaminated waste must be collected in a container or a bag. Upon leaving the unit, an external observer must supervise the performance of PPE removal as per checklists, complementing the thorough cycles of hand sanitizing and equipment removal. According to several reports, PPE removal poses a challenge every day, particularly when doctors experience tiredness or cognitive overload, which results in overlooking of the detail and more contamination. ${ }^{16} \mathrm{~A}$ list of actions to approach the airway in patients suspected or confirmed with COVID-19 is presented in a summarized and structured form (Table 2).

For patients requiring a tracheostomy, an intense neuromuscular blocking must be performed to make sure the patient will not cough while the procedure is being performed. To avoid aerosol release, it is necessary for the anesthetist to have ongoing communication with the surgeon to pause the ventilator during the exhalation phase upon entering the trachea and disconnecting the ventilation circuit. And as in conventional intubation, viral filters, closed circuit suction, and a heat and humidity exchanger must be available. All these measures are mandatory to avoid spreading of the virus. ${ }^{44}$

\section{Central Command Center}

The central command center (CCC) is essential for the daily monitoring of the impact of COVID-19, tracking the inventory, movement, and occupation of hospital beds and intensive care, 


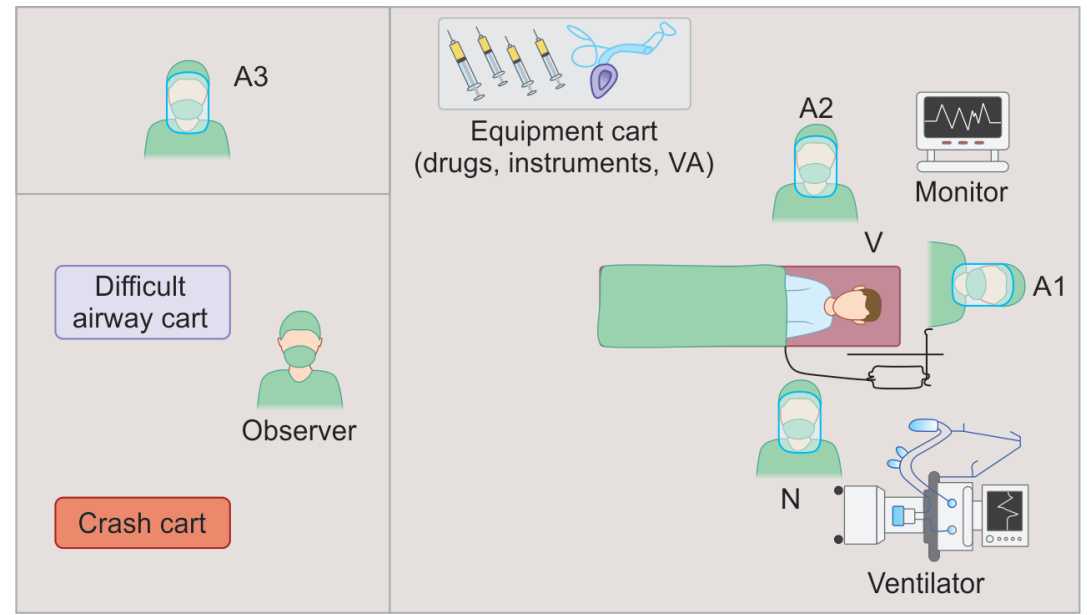

Fig. 3: Multi-discipline team necessary for approaching the airway in a patient with COVID-19 or suspicious of it. It includes the airway expert, represented by anesthesiology (A1), intensivist (A2), and nurses $(\mathrm{N})$ with previously assigned duties, in a safe isolation area, with all the material available: (loaded induction drugs, second generation DSG, V = ready video laryngoscope, ventilator and monitor), external aid (A3), observer verifying the process and accessible emergency carts, defining areas, and preventing crossed infections and unnecessary personnel.

Table 2: Before approaching the airway, it is recommended to have a structured process that allows to guide the sequence of the steps, preintubation, during intubation, rescue maneuvers, and to identify actions that may imply an increased risk to the patient and the operative team

\begin{tabular}{|c|c|c|}
\hline \multicolumn{3}{|c|}{ Approach to the airway (COVID-19 patient or suspected) } \\
\hline Preintubation & Intubation & Rescue maneuver \\
\hline Do: & Do: & Consider: \\
\hline Putting PPE on & $\begin{array}{l}\text { Preoxygenation } \mathrm{FiO}_{2} \\
100 \% / 5 \text { minutes }\end{array}$ & $\begin{array}{l}\text { Disposable flexible } \\
\text { fibroscopy (anticipated } \\
\text { difficult airway in } \\
\text { asleep patient) }\end{array}$ \\
\hline Do: & Do: & Consider: \\
\hline $\begin{array}{l}\text { Verify: isolation } \\
\text { zone, support } \\
\text { personnel, material } \\
\text { complete }\end{array}$ & $\begin{array}{l}\text { Rapid sequence } \\
\text { induction }\end{array}$ & $\begin{array}{l}\text { If videolaryngoscopy } \\
\text { fails (second-genera- } \\
\text { tion DSG) }\end{array}$ \\
\hline Do: & Don't: & Caution: \\
\hline $\begin{array}{l}\text { Develop a plan } \\
\text { Assign roles }\end{array}$ & Ventilate with mask & $\begin{array}{l}\text { Don't delay surgical } \\
\text { airway in case of failure }\end{array}$ \\
\hline Do: & Do: & Don't: \\
\hline $\begin{array}{l}\text { Verify } \\
\text { videolaryngoscope } \\
\text { and DSG (ready) }\end{array}$ & $\begin{array}{l}\text { Apneic ventilation } \\
\text { (1 minute) }\end{array}$ & $\begin{array}{l}\text { Excessively manipulate } \\
\text { endotracheal tube }\end{array}$ \\
\hline Do: & Do: & Don't: \\
\hline \multirow[t]{5}{*}{ Verify drugs (ready) } & Videolaryngoscopy & $\begin{array}{l}\text { Generate cross infec- } \\
\text { tion with contami- } \\
\text { nated equipment }\end{array}$ \\
\hline & Do: & Caution: \\
\hline & $\begin{array}{l}\text { Connect to ventilator } \\
\text { verify intubation } \\
\text { (et } \mathrm{CO}_{2} / \text { thoracic } \\
\text { movement) }\end{array}$ & $\begin{array}{l}\text { Contaminate myself } \\
\text { when removing PPE }\end{array}$ \\
\hline & Don't: & \\
\hline & $\begin{array}{l}\text { Perform Sellick } \\
\text { maneuver }\end{array}$ & \\
\hline
\end{tabular}

continuously updating the situational status. This management mechanism should interact by providing information that is determined or defined by the state and national health authority, be these dependencies of the public or private system. This system has authority to refer patients when there is a greater demand for beds and determines the transfer in conjunction with the hospital network. Likewise, as a priority function is to facilitate the processes of management, coordination, and exchange of information on human and material resources in support of the emergency response operations essential for its operation. The CCC will know the results of epidemiological surveillance, emphasizing the results of laboratory tests, and will also update suspected cases and confirmed cases as new information becomes available. ${ }^{45}$

\section{Safe Operating Room}

\section{Isolation}

Surgeries in confirmed or suspected cases involving aerosolgenerating procedures (AGPs) or others must be performed in an airborne infection isolation room (AlIR). Aerosol generating procedures induce droplets of $5 \mu \mathrm{m}$, which can travel farther and remain suspended in the air longer than bigger drops can. The existing operating room can be converted into an AlIR after modifying the ventilation in a room to keep a negative pressure, proper sealing, and separate access. ${ }^{46}$

The same operating room and the same anesthesia machine are recommended to be used only for COVID-19 cases while the pandemic lasts. An additional heat and moisture exchanger (HME) filter is installed at the espiratory end of the circuit. Both the HME filters and the soda lime must be changed after each patient. The anesthetic drug cart must be kept outside the area. Before beginning each surgery, the anesthetist must place the drugs to be used on a tray to avoid cross infection when manipulating it. Should there be a need for additional drugs, hand hygiene and replacement of gloves must be performed before manipulating the drug cart. ${ }^{47}$ It is important to consider in advance every single item that will be used in additional cases. Consider the points above established in the approach to the airway section for instrumentation. The 
patient must wear an N95 mask when being transferred from the isolation unit along an assigned path with minimum contact with patients or HWs. ${ }^{48}$ Any staff member entering the operating room must wear all the PPE, and the number of staff members involved in the surgery must be restricted. ${ }^{24}$ Staff members participating in AGPs may wear a PAPR. The bispectral index monitor, infusion pumps, cables, monitors, keyboards, screens, and anesthesia machine must be thoroughly cleaned, decontaminating surfaces. The hospital security is responsible for clearing the path, from the emergency room, intensive care unit (ICU), or isolation area to the elevators to the operating room. Patients not requiring care at the ICU after surgery fully recover in the operating room to restrict contamination to only one area. ${ }^{49}$ When the patient is ready for discharge, the path to the isolation area or the ICU is again cleared by security, and HWs or other patients are not allowed in until the used path has been decontaminated. All the staff members have to shower before resuming their regular tasks, and it is very important to register the names of all the participating staff members to make contact tracking easier. ${ }^{50}$

\section{High-risk Procedures}

Surgical procedures resulting in high aerosol generation (AG) include: rigid bronchoscopy; laryngeal endoscopy; tracheotomy; in general, any head and neck procedure where mucous membranes are approached due to their viral load; surgeries with highspeed electric devices (e.g., drills, cutting saw, among others), electrocautery and ultrasonic equipment all generate a smoke cloud containing aerosols which contaminates the environment. ${ }^{44,51}$ Besides the intubation and extubation processes, the anesthetic procedures that can cause AG are: mask manual ventilation, oropharynx suction, high-flow oxygen therapy, high-frequency ventilation, noninvasive mechanical ventilation, nebulizer treatments, awake fiber-optic intubation, and cardiopulmonary resuscitation (CPR). Most of this evidence has been documented in cohort studies and SARS transmission controls in HWs. ${ }^{27,41,52,53}$

\section{Modifying Surgical Techniques to Lower Risks}

$\mathrm{CO}_{2}$ insufflation, electric devices, and high-speed surgical equipment generate a significant volume of aerosols. It is unclear whether laparoscopy increases the risk of exposure to aerosolized viral particles. Aerosols can be contained in the abdomen during laparoscopy; when they are expelled under pressure by releasing the pneumoperitoneum, they can widely scatter. ${ }^{54}$ Caution must be exercised to minimize the possibility of an inadvertent release and the $\mathrm{CO}_{2}$ filter must be filtered using existing technology. ${ }^{55}$ However, viral and bacterial aerosols have been documented on surgical caps in laparoscopic and open procedures. ${ }^{56}$ In such cases, it will be necessary to implement smoke filtration and evacuation devices minimizing exposure in both procedures; it is recommended to use hemostasis and clean the trocar sites, while avoiding splashes; to keep the pneumoperitoneum with the lowest possible pressures; and to minimize the use of the monopolar ${ }^{57,58}$ (Fig. 4).

Considering the lessons learned in Asia and Europe, China and Italy, we can recover several of the published recommendations. ${ }^{58}$ The authors recommend that hospitals should ideally be divided into two main categories: dedicated facilities for COVID-19-positive patients (with limited surgical personnel and operating rooms for those infected patients who require surgery) and others for emergency surgery and urgent oncological procedures in COVID-19-negative patients. As a result of these lessons, efforts should be made to increase the level of care given to operative

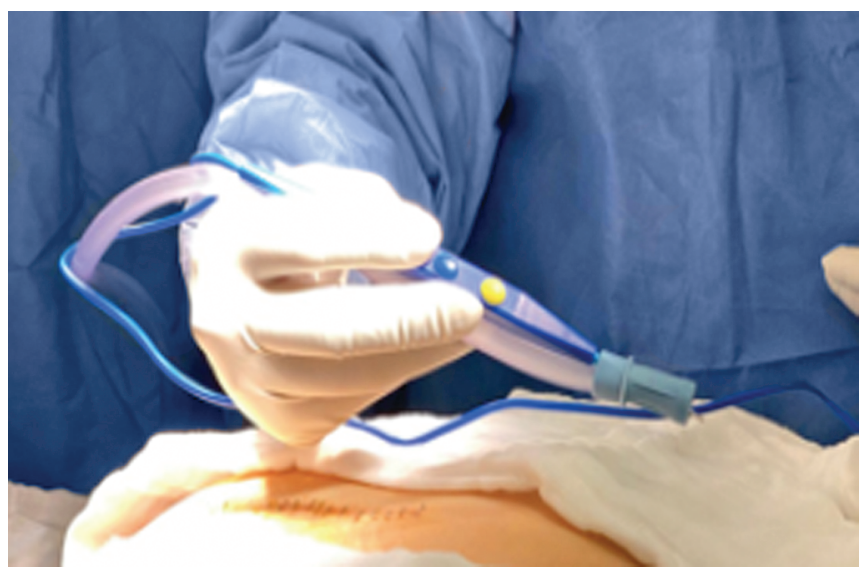

Fig. 4: Way to minimize smoke, using electrocoagulation connected to an aspirator

personnel, surgeons, anesthetists, nurses, and all the people in transit in the operating room. Proper bidirectional protection clothing (protection glasses, goggles, mask, and body protective clothing) must be a routine, and so must the proper removal and decontamination phases. When treating a suspected or diagnosed patient, a tertiary clothing code (higher protection code) must be enforced, as well as reinforcement of the operating room ventilation protocols and installation of air-purifying equipment. From this pandemic on, special emphasis must be given to labor protection, stricter protocols, use of artificial pneumoperitoneum, and the hazards of aerosol diffusion for the members of the surgical team. In order to effectively fight the possibility of a prolonged COVID-19 outbreak, it is imperative to establish new practice standards to accept patients in the future. This must cover from the preoperative medical evaluation up to the final differential diagnosis. Every surgery patient must complete the preoperative assessment, whether they are symptomatic or not. The intention is to lower the contagion risk for the operative personnel, which would result in reducing the number of staff members. In any case, all the staff members must comply with the regulation regarding protection, prevention, and management of aerosol dispersion during surgeries and procedures, whether through laparoscopy or open surgery (e.g., laparotomy). The instruments must be kept free from blood and other body fluids. Special care must be given to establishing a pneumoperitoneum, hemostasis, and cleansing of trocar or incision sites to avoid any body fluid dispersion caused by uncontrolled air leaks or laparotomy. Liberal use of suction devices to eliminate smoke and aerosols during surgeries, and, particularly, before proceeding from laparoscopy to open surgery or any extraperitoneal maneuver. Avoid using two-way pneumoperitoneum insufflators to prevent colonization by pathogens from the circulating aerosol on the pneumoperitoneum circuit or the insufflator (Fig. 5). Keep the pneumoperitoneum pressure and the $\mathrm{CO}_{2}$ ventilation to the lowest possible levels without compromising the exposure of the surgical field and minimize the Trendelenburg position. This reduces the effect of the pneumoperitoneum on the lung function and on circulation, lowering the susceptibility to pathogens. Configuration of the electrocautery in terms of intensity must be as low as possible. Avoid long dissection time periods at the same place through electrocoagulation/cut or use of ultrasonic devices to reduce surgical smoke. Particular caution is required to prevent acute injuries or damage to the protective equipment, particularly on gloves and body protection. After the patient leaves 


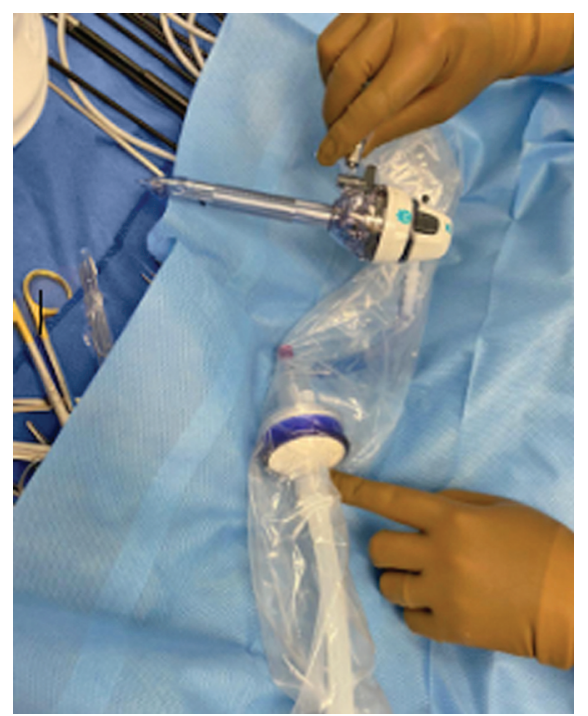

Fig. 5: Way to add filters to the insufflation hose and the trocar to avoid bidirectional contamination

the operating room, the protocols related to postoperative cleaning and disinfection protocols must be thoroughly observed as per hospital regulations. The devices used on patients with a suspected or confirmed infection must undergo a separate disinfection process, followed by proper labeling. It is likewise mandatory to specifically dispose of clinical waste in separate containers.

We believe that an effective communication among the surgical staff and strict attention to detail will be fundamental to the surgical care process and to the logistics of any procedure.

\section{Risk Classification in Elective Surgery}

Continuity of the elective procedures will depend on the statements and implementations in response to the pandemic in each hospital and institution. The quickly spreading outbreak imposes an unprecedented burden on the efficacy, sustainability, infrastructure, and response ability of the healthcare systems around the world. There are asymptomatic patients who unknowingly eliminate the virus, exposing other inpatients, outpatients, and healthcare providers with a high probability of contracting COVID-19. Likewise, the possible consequences of elective surgery cancellation may generate an unfavorable impact on patients. There are elective surgery cases, which pose a potential to inflict significant damage if cancelled or delayed because we are talking about vulnerable population, as is the case of oncological patients, and a high number of nonurgent elective surgeries will certainly become urgent at some point. ${ }^{59,60}$ Elective procedures can be classified as "essential," which implies that there is a higher risk of adverse results from delaying surgical care for an indefinite period of time, in comparison to "nonessential" ones, which makes reference to nonmedically urgent elective procedures. ${ }^{61}$ Evaluation by a multidiscipline team is recommended, which will objectively determine the medical risks of delaying the treatment. (Table 3) describes recommendations on some specific procedures based on the clinical stage of the patient.

\section{Conclusion}

Preparation in the perioperative period in the presence of the COVID-19 pandemic involves a very complex environment, given
Table 3: Classification of elective surgery according to the patient's risk and clinical condition

\begin{tabular}{|c|c|c|}
\hline Action & Clinical status & Procedures \\
\hline \multirow[t]{15}{*}{ Not to defer } & \multirow[t]{11}{*}{ Emerging } & $\begin{array}{l}\text { Bleeding and } \\
\text { thrombosed } \\
\text { hemorrhoids }\end{array}$ \\
\hline & & $\begin{array}{l}\text { Sepsis: big perianal } \\
\text { abscess, necrotizing } \\
\text { fasciitis }\end{array}$ \\
\hline & & Vascular lesion \\
\hline & & $\begin{array}{l}\text { Major trauma (firearm } \\
\text { or cold weapon injury, } \\
\text { multiple trauma) }\end{array}$ \\
\hline & & Peritonitis \\
\hline & & $\begin{array}{l}\text { Abdominal } \\
\text { perforation/ } \\
\text { pneumoperitoneum }\end{array}$ \\
\hline & & Tracheostomy \\
\hline & & Strangulated hernia \\
\hline & & Urgent C-section \\
\hline & & $\begin{array}{l}\text { Ruptured ectopic } \\
\text { pregnancy }\end{array}$ \\
\hline & & $\begin{array}{l}\text { Endoscopy and } \\
\text { colonoscopy with } \\
\text { copiously bleeding } \\
\text { digestive tube }\end{array}$ \\
\hline & \multirow[t]{4}{*}{ Urgent } & Appendicitis \\
\hline & & Open fractures \\
\hline & & Acute or \\
\hline & & Choledocholithiasis \\
\hline Consider to defer* & $\begin{array}{l}\text { "Essential" elective } \\
\text { procedures }\end{array}$ & $\begin{array}{l}\text { Cancer } \\
\text { Closed fractures with } \\
\text { no evidence of vascular } \\
\text { or nerve damage } \\
\text { Neoplasm after } \\
\text { neoadjuvant therapy } \\
\text { In situ or atypical } \\
\text { lesions } \\
\text { Hysterectomy (due } \\
\text { to myomatosis, } \\
\text { endometriosis) }\end{array}$ \\
\hline \multirow[t]{5}{*}{ Elective } & \multirow[t]{5}{*}{ Defer "nonessential" } & $\begin{array}{l}\text { Prophylactic cancer } \\
\text { surgery }\end{array}$ \\
\hline & & Plastic surgery \\
\hline & & Bariatric surgery \\
\hline & & Sports surgery \\
\hline & & $\begin{array}{l}\text { Articular replacement } \\
\text { Family planning surgery }\end{array}$ \\
\hline
\end{tabular}

${ }^{*}$ Consideration must be given to infrastructure, personnel, available equipment, pandemic's current state, patient's clinical evolution, and the stage of oncological illnesses

its high contagion level, and poses a challenge on all levels of care, depending on the different phases of the pandemic with an exponential demand of resources that exceeds any health system. Huge modifications will be required, among which stand out infrastructure, processes, guidelines, personnel management, infection prevention strategies, and contention measures, which minimize transmission of the sickness and protect the HWs with 
the proper PPE. It will be of the utmost importance to develop hospital protocols based on risk classification-to utilize resources and identify nonessential surgical resources that guarantee an optimal, safe, planned, and timely care during the perioperative period, reducing the risks of viral transmission to other patients and HWs. Medicine around the world is learning from COVID-19 every day. Scientific evidence is accumulating rapidly, improving our understanding of an enemy that is imperceptible and invisible to the human eye. The goal is to promote the safety of the anesthetist who is responsible for intubation and the surgical equipment during the perioperative period, which ensures efficient conditions for managing the growing number of infected patients who will require our care.

\section{References}

1. Wu Z, Mc Googan J. Characteristics of and important lessons from the coronavirus disease 2019 (COVID-19) outbreak in China: summary of a report of 72314 cases from the Chinese center for disease control and prevention. JAMA 2020(13). DOI: 10.1001/jama.2020.2648.

2. Johns Hopkins CSSE, Coronavirus COVID-19 Global Cases. [Online].; 2020 [cited April 2020. Available from: https:// gisanddata.maps.arcgis.com/apps/opsdashboard/index.html\#/ bda7594740fd40299423467b48e9ecf6.

3. Coccolini F, Sartelli M, Kluger Y, et al. COVID-19 the showdown for mass casualty preparedness and management: the cassandra syndrome. World J Emerg Surg 2020;15(1):26. DOI: 10.1186/s13017-020-00304-5.

4. Correia M, Ramos R, Von Bahten L. The surgeons and the COVID-19 pandemic. Rev Col Bras 2020;47:1-6.

5. Aminian A, Safari S, Razeghian-Jahromi A, et al. COVID-19 outbreak and surgical practice: unexpected fatality in perioperative period. Ann Surg 2020;272(1):e27-e29. DOI: 10.1097/SLA.0000000000003925.

6. Brindle M, Gawande A. Managing COVID-19 in surgical systems. Ann Surg 2020(1). DOI: 10.1097/SLA.0000000000003923.

7. Wang D, Hu B, Hu C, et al. Clinical characteristics of 138 hospitalized patients with 2019 novel coronavirus-infected pneumonia in Wuhan, China. JAMA 2020;323(11):1061-1069. DOI: 10.1001/jama.2020.1585.

8. Li Q, Guan X, Wu P, et al. Early transmission dynamics in Wuhan, China, of novel coronavirus-infected pneumonia. N Engl J Med 2020;382(13):1199-1207. DOI: 10.1056/NEJMoa2001316.

9. Phan LT, Sweeney D, Maita $D$, et al. Respiratory viruses on personal protective equipment and bodies of healthcare workers. Infect Control Hosp Epidemiol 2019;40(12):1356-1360. DOI: 10.1017/ ice.2019.298.

10. Casanova L, Alfano-Sobsey E, Rutala W, et al. Virus transfer from personal protective equipment to healthcare employees' skin and clothing. Emerg Infect Dis 2008;14(8):1291-1293. DOI: 10.3201/ eid1408.080085.

11. Zhang Y, Cheng S. Estimating preventable COVID-19 infections related to elective outpatient surgery in Washington state: a quantitative model. medRxiv 2020. DOI: https://doi.org/10.1101/2020.03.18.2003 7952.

12. Health Leaders. Surgeon general urges Providers to "consider stopping elective surgeries." Hospitals push back. [Online].; 2020 [cited 2020 April. Available from: https://www.healthleadersmedia. com/clinical-care/surgeon-general-urges-providers-considerstopping-elective-surgeries-hospitals-push.

13. ACS. COVID-19: Guidance for Triage of Non-Emergent Surgical Procedures. [Online].; 2020 [cited 2020 April. Available from: https:// www.facs.org/covid-19/clinical-guidance/triage.

14. ACS. Maintaining Trauma Center Access \& Care during the COVID19 Pandemic: Guidance Document for Trauma Medical Directors. [Online].; 2020 [cited 2020 April. Available from: https://www.facs. org/quality-programs/trauma/maintaining-access.

15. Kamming D, Gardam M, Chung F. Anaesthesia and SARS. Br J Anaesth 2003;90(6):715-718. DOI: 10.1093/bja/aeg173.
16. Sorbello M, El-Boghdadly K, Di Giacinto I, et al. The Italian coronavirus disease 2019 outbreak: recommendations from clinical practice. Anaesthesia 2020(6). DOI: 10.1111/anae.15049.

17. Australian Society of Anaesthetists. Anaesthesia and caring for patients during the COVID-19 outbreak. [Online].; 2020 [cited 2020 March. Available from: https://www.asa.org.au/ wordpress/wp-content/uploads/News/eNews/covid-19/ASA airway_management.pdf.

18. WHO, Rational use of personal protective equipment for coronavirus disease 2019 (COVID-19). [Online].; 2020 [cited 2020 April. Available from: https://apps.who.int/iris/bitstream/handle/10665/331215/ WHO-2019-nCov-IPCPPE_use-2020.1-eng.pdf.

19. Matava C, Yu J, Denning S. Clear plastic drapes may be effective at limiting aerosolization and droplet spray during extubation: implications for COVID-19. Can J Anesth 2020;67(7):902-904. DOI: 10.1007/s12630-020-01649-w.

20. CDC, Decontamination and Reuse of Filtering Facepiece Respirators. [Online].; 2020. Available from: https://www.cdc.gov/ coronavirus/2019-ncov/hcp/ppe-strategy/decontamination-reuserespirators.html.

21. CDC, Strategies for Optimizing the Supply of Isolation Gowns. [Online].; 2020. Available from: https://www.cdc.gov/coronavirus/2019-ncov/ hcp/ppe-strategy/isolation-gowns.html.

22. CDC, Strategies for Optimizing the Supply of Eye Protection. [Online].; 2020. Available from: https://www.cdc.gov/coronavirus/2019-ncov/ hcp/ppe-strategy/eye-protection.html.

23. CDC, Strategies for Optimizing the Supply of Disposable Medical Gloves. [Online].; 2020. Available from: https://www.cdc.gov/ coronavirus/2019-ncov/hcp/ppe-strategy/gloves.html.

24. CDC, What healthcare personnel should know about caring for patients with confirmed or possible coronavirus disease 2019 (COVID19). [Online].; 2020 [cited 2020 Marzo. Available from: https://www. cdc.gov/coronavirus/2019-ncov/hcp/caring-for-patients-H.pdf.

25. Novak D, Why, Where, and How PAPRs Are Being Used in Health Care: Workshop Summary. In Medicine. Io. The Use and Effectiveness of Powered Air Purifying Respirators in Health Care: Workshop Summary. Washington (DC); 2015.

26. Zamora J, Murdoch J, Simchison B, et al. Contamination: a comparison of 2 personal protective systems. CMAJ 2006;175(3):249-254. DOl: 10.1503/cmaj.060094.

27. Christian MD, Loutfy M, McDonald LC, et al. Possible SARS coronavirus transmission during cardiopulmonary resuscitation. Emerg Infect Dis 2004;10(2):287-293. DOI: 10.3201/eid1002.030700.

28. Wax R, Christian M. Practical recommendations for critical care and anesthesiology teams caring for novel coronavirus (2019-nCoV) patients. Can J Anaesth 2020;67(5):568-576. DOI: 10.1007/s12630020-01591-x.

29. IHME, COVID-19 estimation updates. [Online];; 2020 [cited 2020 April. Available from: http://www.healthdata.org/covid/updates.

30. Bulk Nitril Gloves (BNG). Types of Medical Gloves and Their Uses. [Online].; 2018 [cited 2020 April. Available from: https:// bulknitrilegloves.com/types-of-medical-gloves-and-their-uses/.

31. Chen X, Shang Y, Yao S, et al. Perioperative care provider's considerations in managing patients with the COVID-19 infections. Transl Perioper \& Pain Med 2020;7:216-224. DOI: 10.3389/ fmed.2020.00040.

32. ECDC, Safe use of personal protective equipment in the treatment of infectious diseases of high consequence. [Online].; 2014 [cited 2020 March. Available from: https://www.ecdc.europa.eu/en/ publications-data/safe-use-personal-protective-equipmenttreatment-infectious-diseases-high.

33. Peng $\mathrm{P}, \mathrm{Ho} \mathrm{P}$, Hota $\mathrm{S}$. Outbreak of a new coronavirus: what anaesthetists should know. Br J Anaesth 2020;124(5):497-501. DOI: 10.1016/j.bja.2020.02.008.

34. Luo M, Cao S, Wei L, et al. Precautions for Intubating patients with COVID-19. Anesthesiology 2020(6). DOI: 10.1097/ ALN.0000000000003288. 
35. Zucco L, Levy N, Ketchandji D, et al. Perioperative considerations for the 2019 novel coronavirus (COVID-19). APSF 2020. 35.

36. Sorbello M, Afshari A, De Hert S. Device or target? A paradigm shift in airway management: Implications for guidelines, clinical practice and teaching. Eur J Anaesthesiol 2018;35(11):811-814. DOI: 10.1097/ EJA.0000000000000893.

37. Casey JD, Janz DR, Russell DW, et al. Bag-mask ventilation during tracheal intubation of critically ill adults. N Engla J Med 2019;380(9):811-821. DOI: 10.1056/NEJMoa1812405.

38. Sorbello M. Aristotle, Galileo and Sellick: The unsolved dilemma of cricoid pressure. Trends Anaesthesia Crit Care 2016;6:1-2. DOI: 10.1016/j.tacc.2015.11.001.

39. Driver BE, Prekker ME, Klein LR, et al. Effect of use of a bougie vs endotracheal tube and stylet on first-attempt intubation success among patients with difficult airways undergoing emergency intubation: a randomized clinical trial. JAMA 2018;319(21):2179-2189. DOI: 10.1001/jama.2018.6496.

40. Sorbello M, Cortese G, Gaçonnet C, et al. A modified bailey's manoeuvre for supraglottic airway continuum using LMA Protector ${ }^{\mathrm{TM}}$. Indian J Anaesth 2019;63(1):78-80. DOI: 10.4103/ija.IJA_502_18.

41. Tran K, Cimon K, Sevem M, et al. Aerosol generating procedures and risk of transmission of acute respiratory infections to healthcare workers: a systematic review. PLoS ONE 2012;7(4):e35797. DOI: 10.1371/ journal.pone.0035797.

42. Fan E, Brodie D, Slutsky A. Acute respiratory distress syndrome: advances in diagnosis and treatment. JAMA 2018;319(7):698-710. DOI: 10.1001/jama.2017.21907.

43. Respiratory care committee of Chinese Thoracic Society. [Expert consensus on preventing nosocomial transmission during respiratory care for critically ill patients infected by 2019 novel coronavirus pneumonia]. Zhonghua Jie He He Hu Xi Za Zhi 2020;17(0):E020. DOI: 10.3760/cma.j.issn.1001-0939.2020.0020.

44. Givi B, Schiff BA, Chinn SB, et al. Safety recommendations for evaluation and surgery of the head and neck during the COVID-19 pandemic. JAMA Otolaryngol Head Neck Surg 2020(6). DOI: 10.1001/ jamaoto.2020.0780.

45. OPS. Reorganization and progressive expansion of health services for the response to the COVID-19 pandemic. Techn Work Doc 2020;1:3-17.

46. Curry International Tuberculosis Center. Tuberculosis Infection Control: A Practical Manual for Preventing TB. [Online].; 2011 [cited 2020 April. Available from: https://www.currytbcenter.ucsf. edu/products/tuberculosis-infection-control-practical-manualpreventing-tb.

47. Tompkins B, Kerchberger J. Special article: personal protective equipment for care of pandemic influenza patients: a training workshop for the powered air purifying respirator. Anesth Analg 2010;111(4):933-945. DOI: 10.1213/ANE.0b013e3181e780f8.
48. Peng $\mathrm{P}$, Wong $\mathrm{D}$, Bevan $\mathrm{D}$, et al. Infection control and anesthesia: lessons learned from the toronto SARS outbreak. Can J Anaesth 2003;50(10):989-997. DOI: 10.1007/BF03018361.

49. Chee V, Khoo M, Lee $S$, et al. Infection control measures for operative procedures in severe acute respiratory syndrome-related patients. Anesthesiology 2004;100(6):1394-1398. DOI: 10.1097/00000542200406000-00010.

50. Ti L, Ang L, Foong T, et al. What we do when a COVID-19 patient needs an operation: operating room preparation and guidance. Can J Anaesth 2020(6):1-3. DOI: 10.1007/s12630-020-01617-4.

51. CDC, Identification of Aerosol Production during Surgical Procedures. [Online].; 1994 [cited 2020 April. Available from: https://www.cdc.gov/ niosh/nioshtic-2/00229128.html.

52. Chan MTV, Chow BK, Lo T, et al. Exhaled air dispersion during bagmask ventilation and sputum suctioning - implications for infection control. Sci Rep 2018;8(1):198. DOI: 10.1038/s41598-017-18614-1.

53. Hui DS, Chow BK, Lo T, et al. Exhaled air dispersion during high-flow nasal cannula therapy versus CPAP via different masks. Eur Respir J 2019(4):53. DOI: $10.1183 / 13993003.02339-2018$.

54. DesCoteaux J, Picard P, Poulin E, et al. Preliminary study of electrocautery smoke particles produced in vitro and during laparoscopic procedures. Surg Endosc 1996;10(2):152-158. DOI: 10.1007/BF00188362.

55. Tao KX, Zhang BX, Zhang P, et al. Recommendations for general surgery clinical practice in novel coronavirus pneumonia situation. Zhonghua Wai Ke Za Zhi 2020(0). DOI: 10.3760/cma.j.issn.0529-5815.2020. 0001

56. Schultz L. Can efficient smoke evacuation limit aerosolization of bacteria? Aorn J 2015;102(1):7-14. DOI: 10.1016/j.aorn.2015. 04.023.

57. Li C, Pai J, Chen C. Characterization of smoke generated during the use of surgical knife in laparotomy surgeries. J Air Waste Manag Assoc 2020;70(3):324-332. DOI: 10.1080/10962247.2020.1717675.

58. Zheng M, Boni L, Fingerhut A. Minimally invasive surgery and the novel coronavirus outbreak: Lessons learned in China and Italy. Ann Surg 2020(1). DOI: 10.1097/SLA.0000000000003924.

59. Yu G, Lou Z, Zhang W. Several suggestion of operation for colorectal cancer under the outbreak of corona virus disease 19 in China. Zhonghua Wei Chang Wai Ke Za Zhi 2020;23(3):9-11. DOI: 10.3760/ cma.j.issn.1671-0274.2020.03.002.

60. Zhang S. What It Really Means to Cancel Elective Surgeries. [Online].; 2020 [cited 2020 March. Available from: https://www.theatlantic.com/ science/archive/2020/03/patients-whose-surgeries-are-canceledbecause-coronavirus/608176/.

61. Stahel P. How to risk-stratify elective surgery during the COVID-19 pandemic? Patient Saf Surg 2020;14(1):8. DOI: 10.1186/s13037-02000235-9. 